\title{
I'm Somali and I'm Christian: A dilemma for religion and identity in the context of migration in Southern Africa
}

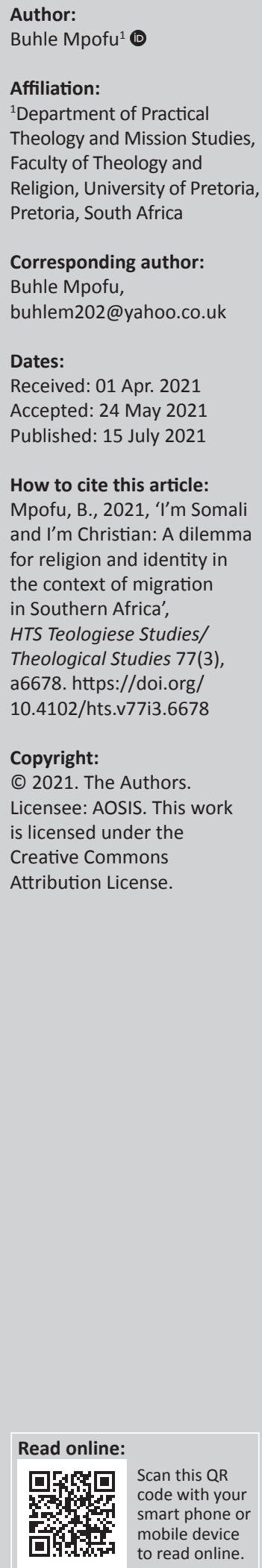

This contribution is one of a series that aimed at publishing significant findings from the research conducted for a $\mathrm{PhD}$ study where emerging themes were isolated and discussed. During one of the focus group conversations, Abdul (not his real name) explained how his Somali-Christian identity presented a dilemma whilst he lived with fellow Muslim Somali nationals when he was displaced during the 2015 xenophobic violence in Johannesburg. Firstly, this contribution discusses a general overview of the situation of migration and then his situation is explored from the themes, which emerged from this study from the lens of bicultural and acculturation processes of identity formation. Although this was not a representative sample of male foreign migrant experiences, analysing Abdul's situation within a post-colonial and bicultural acculturation paradigm revealed the 'embedded' trajectories at the interface between religion, identity and migration in social and economic processes of transformation. Sketching Abdul's experiences through these lenses also generated contested processes on the interface of religion and identity that reflect the significance of the role played by religion in identity constructions which are open to change (and sometimes present a dilemma), as life circumstances fluctuate with complex interactions in search of survival strategies to ward off any potential threats to a flourishing life. Such survival strategies highlight how these encounters generate hybrid identities and discourses with new boundaries, which, although fluid, volatile and situational, are reminiscent with historical and odious notions of colonialism that present African migrants as undesired foreigners whilst portraying other western and Asian migrants in cosy terms such as expatriates and tourists.

Contribution: Exploring the relevance of migrant expressions within the context of identity constructions and socio-economic framework demonstrates how contested processes of socio-economic and religious transformation reflect the significance of the role played by religion on identity constructions. These constructions are articulated through fluid and complex encounters, which fluctuate to generate hybrid identities and migrant survival discourses.

Keywords: identity; religion; migration; bicultural acculturation; social transformation; South Africa.

\section{Introduction}

This contribution analysed statements, which emerged from one of the focus group participants who was displaced during 2015 xenophobic violence in Mayfair Johannesburg, South Africa. Abdul was one of the migrants affected by xenophobic violence in 2008 and in 2015 when he reflected on his experiences and relayed how he lost his business and ended up seeking shelter among Muslim Somalis. Given that he had converted to Christianity, this presented a dilemma for him as he had to navigate a diverse cultural and religious landscape to survive in the face of hostility. Although the findings are significant, it is important to state that these findings are not representative of all migrant experiences but do highlight the implications of changing identity processes in the face of diversity and fluid socio-economic and political landscapes. More work still needs to be performed to triangulate these findings and draw inferences from different perspectives. Before unpacking statements from Abdul, what follows is a discussion on how this study emerged in the face of hostility as means to explore hybrid identity trends, social transformation and bicultural acculturation approaches as intersecting trajectories at the interface between religion, identity and the role of migration within the context of identity formation processes.

Note: Special Collection: New Landscapes in Identity: Theological, Ethical and Other Perspectives, sub-edited by John Klaasen (University of the Western Cape). 
This discussion is located in the context of a statement on the title; 'I'm Somali and I'm Christian', a statement, which emerged from a transcript of a focus group discussion with foreign migrants in one of the protestant congregations at Mayfair, Johannesburg, in 2015. The focus group was moderated to explore their lived experiences of foreign migrants in both church and society as it emerged that these encounters can be categorised into 'sociological, theological, ecclesial and missional themes of recognition, human dignity, shame, vulnerability and competition, family of God, compassion fatigue, (in)visible church and transnational God' (Mpofu 2015). Consequently, these themes made it possible to interrogate and unpack the implications of theses migrant experiences towards laying a foundation for a contextual theology of migration ${ }^{1}$ grounded in life-affirming values $^{2}$ and dignity for vulnerable people on the move.

Building on this work, a sample of a male foreign migrant's experiences is analysed through the social transformation and bicultural acculturation approach to sketch trajectories at the interface between religion, identity and the role of migration in social transformation within the context of exploring the role of religion in identity formation processes within the diverse African context characterised by a complex colonial history. There is a need to interrogate these trajectories from the perspective of religion. What does it mean to convert from Islam and be a protestant Christian male migrant living in a diverse urban, African community? As Ngwena (2019) has observed:

[C] Jurrent inhabitants of the continent come with a full complement of diverse 'racial' ancestry; some black, some white and some neither black nor white. Moreover, they come with multiple or intersectional identities ... using 'race' as an essential marker for African identity is exclusionary; ... We should concede that, like all identities, racial identities are subject to the play of history such that they are always in the making. We should think less of identity as a completed representational entity that is fixed and closed. Rather ... we are better served by a concept that treats identity as an unfinished process of identification, which in the end amounts to positioning. Identities do not signal a stable core of the pure self that unfolds through the vicissitudes but remain the same. Instead, identities are made within historical and cultural discourses and are open to 'contamination'. Identity is becoming and being ... Ultimately, the enunciation of an identity, whether African or otherwise, is a positional attempt to articulate solidarity and allegiance with another person or group, and not a claim to the completeness of the identity. (p. 1)

The question of framing an inclusive African identity still remains a challenge as a result of pitfalls, which arise from racial challenges of the past, and there is a need to explore these identity processes deeply. Given the double dimension of racist practices and xenophobic hostility, which persist in South African communities, African migrants are often

\footnotetext{
1.Note that this contribution did not adequately develop a contextual theology of migration nor deeply analyse the implications of these findings for Christian mission. However, the research made significant findings, which lay the foundation for future However, the research made significant findings, which lay the foundation
research, and there is a need for more work to be done in that regard.
}

2.By life-affirming values, I mean tolerance and human dignity within the context of human rights for all people. on the receiving end for both forms of violence and discrimination. These racial divisions and hostility towards foreign migrants are on the rise because of coronavirus disease 2019 (COVID-19) restrictions - which have normalised marginalisation of the poor through social distancing measures and the economic meltdown, which has worsened the plight of the poor and economically marginalised communities.

The recent socio-economic disruptions have demonstrated that social identity constructions remain open to change as circumstances and interactions fluctuate. These changes call for historically situated interventions as most of the challenges in contemporary social and economic structures are a product of historical socio-economic and political context. The experience of migration sets the agenda not only as a barometer for socio-economic organisation (see Mpofu \& Settler 2017), but also for the church's missional activities as the experience of migration constitutes the mission-ecclesial hermeneutical tool for responding to some contextual challenges in society. It is in managing and celebrating the diversity of our communities that the Church can find its meaningful expression of worshiping God, but such a positive approach towards the situation of migration will not come naturally - it will require concerted efforts from all of us to address exclusion and discrimination in all its forms.

Dealing with the challenges faced by refuges in East Africa, Orobator (2005:171) observed that 'a place to feel at home portrays a powerful ecclesial counter-witness to the politics of socio-economic exclusion and discrimination'. A 'counterwitness' to the South African politics of economic exclusion and discrimination will require not only regimes of hospitality anchored on political rhetoric, but also appreciating the complex identities that constitute diverse components of the 'rainbow nation' - including appreciating and appropriating the agency of African migrants in the development of communities. We have to also acknowledge that the Christian mission and its identity are a product of various colonial encounters, which involved missionaries working alongside traders and colonial administrators through identity processes that spurn from the extension of power by the powerful states that continue to use globalisation as a front for their neo-liberal economic activities. Therefore, symbols of Christian mission cannot be isolated from those of the colonisers, although it is possible to isolate discourses of oppressor-oppressed from those of the missionaryindigenous community encounters. The significance of symbols, images or sayings from encounters between missionaries and indigenous communities has been underscored by de-Gruchy and Villa-Vicencio when they pointed out:

Scripture and tradition are essential elements of any Christian theology. Without the stories, symbols, images, and sayings linked to the origin of Christian understandings of the world, and without the subsequent history of those who have sought to demonstrate in word and deed what difference these understandings make in life, there is no Christian identity at all and thus no need for Christian theology. (eds. De Gruchy \& Villa-Vicencio 1994:37) 
Christian symbols are no doubt important to preserve, but what constitutes the Christian identity in an African context? This is another important question, which deserves some attention. For purposes of this discussion, it is important to raise all these pertinent issues as we build up to reflect on the statements from Abdul. Raising these important questions is intended to highlight the intersecting trajectories between contemporary urban migration and historical Christian mission which was underpinned by the movement of missionaries alongside colonial administrators who advanced the economic and political agenda of the powerful western nations.

Therefore, more studies need to closely interrogate the influence of western culture on Christian and African identify formation processes.

Given what Ndlovu-Gatsheni (2018) and Nel (2009) identified a crisis of identity and migration in post-colonial southern Africa, loss of identity among migrants as a result of displacement in South African communities deserves further attention as it is particularly compounded by the historical racial divisions that have roots from the apartheid era. The question of framing an inclusive African identity still remains a challenge as a result of pitfalls, which arise from racial challenges. In an article dedicated to the celebration of Africa Month in May 2019, Charles Ngwena (2019) raised this question:
... How might we frame African identity inclusively, so that we holistically acknowledge the heterogeneities among Africans but without falling hostage to 'race'? [and shed some light on how it can be approached] ... We cannot answer this in dogmatic terms or within a short space, but can begin to think about some of the foundational architecture of inclusive Africanness. In constructing this foundation, we need not deny the materiality of 'race' in our daily identitarian lives and its place in the naming of Africa and Africans. Ultimately, we need a transformative identitarian template to ensure that we develop a historically conscious, progressive and, above all, inclusive notion of Africanness that shies away from nativism and gives recognition to all people who belong to Africa. (p. 1)

For Ngwena (2019:1), reflecting on the question of African identity 'is important for several reasons', among them, 'to pay homage to the diversities that make up Africa against the backdrop of a colonial history...' (Ngwena 2019:1). In a book developing an epistemology for constructing the hermeneutics of Africanness today, Ngwena (2018) further explored this subject as he interrogated the making of African race, culture(s) and sexuality(ies) 'in ways that are not just historically conscious but also have a heuristic capacity to contest nativism from the outside as well as from within'. There is a need to broaden the scope of this conversation to include the role of religion and religiosity within these transactional identity formation processes that intersect with culture, race and sexuality. Ngwena's approach is helpful for this discussion in that it underscores the need for a contextually grounded and interpretive approach to understanding African identity without losing consciousness to the historical colonial legacies.
The complexity of these identity discourse processes is even more telling when we ask: what is the role of religion in identity formation processes within the culturally diverse context of Africa? There has been creative scholarly engagement and growing epistemological interest regarding instrumental and, sometimes, ambiguous expressions of religious capital especially in navigating borders and negotiating peaceful settlements and co-existence between migrants and host communities. Within the context of transnational migration, such scholarly work reflects the fluid nature of religion or theology in ways that impact mobility and social transformation process as embodied in the works inter alia: Agamben (2005) The State of Exception; Adogame, Osemime and Spickard (eds. 2010) Religion Crossing Boundaries: Transnational Religious and Social Dynamics in Africa and the New African Diaspora; Adogame, Afe and Shobana Shankar (eds. 2012) Religion on the Move! New Dynamics of Religious Expansion in a Globalizing World; Adogame (2013) The African Christian Diaspora: New Currents and Emerging Trends in World; Agbiji and Swart (2015) Religion and Social Transformation in Africa: A Critical and Appreciative Perspective, to mention but a few selected examples of key texts.

The few examples cited above are not in any order other than the publication dates. However, they all reflect a growing concern in the academia regarding religion, boundaries and social transformation. This contribution builds on these studies to highlight how these trajectories intersect with religion and identity formation processes in ways that draw from theological creativity. Within the South African context, this phenomenon has previously been examined by Bekker and Leilde (1999) in their work, Identity Construction 'From Above': The Western Cape Province as Case Study. An Interim Report on Research into Emerging Provincial Identities in the Western Cape, in Stellenbosch University Department of Sociology. In another related project, Bekker, Dodds and Khosa et al. (2001) went on to interrogate what they termed Shifting African Identities working with the Human Sciences Research Council in Pretoria to mention but a few.

\section{Social transformation and bicultural acculturation theories}

Social transformation is a complex process that differs with each context and therefore attracts the application of different notions contingent on particular contexts within which they occur. Although Western scholars have tended to approach transformations from politically motivated ascriptions, which have been labelled as 'crypto-colonial' rule over the European margins (Adam et al. 2019) within the South African context, debates around the concepts of 'social transformation' are generally underpinned by resistance to colonialism and apartheid as reflected in the works of Boraine (2006), Transitional Justice: A Holistic Interpretation; Benatar (2008) Justice, Diversity and Racial Preference: A Critique of Affirmative Action; Erasmus (2010) Reformulating Racialised Citizenship(s) for South Africa's Interregnum. Transformations; Habib (2013) South Africa's Suspended Revolution, and 
some theologians like Pillay (2020) recently approached transformation from the perspective of COVID-19 to highlight the need for the Church's flexibility.

This contribution approaches social transformation as gradual and fundamental changes in socio-economic and political activities to redress the imbalances on the past. The notion of social transformation is universal, but there are different views on the how it should be conducted especially with regard to creating equal economic opportunities in communities where the poor have been historically marginalised as a result of colonialism and apartheid. In South Africa, for example, there are disagreements on the necessary policies required to fast track changes in land ownership given the corrupt activities where political elites have exploited the mechanisms of change for their own personal gain. However, as Stephen Castles (2001) has observed:

$[D]$ espite international interchange between social scientists, there was (and still is) considerable national specificity in the modes of organisation, the theoretical and methodological approaches, the research questions and the findings of the social sciences. (p. 17)

One of the concepts, which have been employed by scholars to understand identity formation processes, is the bicultural acculturation approach. As Arel (2014) has observed, bicultural acculturation is a process whereby migrants maintain meaningful connection with their heritage culture whilst learning to manoeuvre new cultural landscapes in host communities. Models of immigrant acculturation suggest that there is no complete rejection of the heritage culture and where it is abandoned, this is associated with stress. Migrants often resort to a bicultural negotiation in which they simultaneously integrate into the host culture whilst maintaining their heritage culture in a process that Vertovec (2009) has labelled 'simultaneous embeddedness' and identified two kinds of 'embeddedness', as being 'relational embeddedness', - which involves actors' personal relations with one another, including norms, sanctions, expectations and reciprocity. The second is structural embeddedness - which describes different levels of social relationships whereby other players get involved beyond direct economic transactions.

\section{Lived realities on the experience of migration in brief}

In the sections that follow, an example of how migrants navigate fluid religio-cultural landscapes to forge hybrid identities is examined through the lenses of bicultural acculturation to encourage appreciation of the role played by religion in societal and identify formation processes within the context diversity.

Understanding that religious and social identity constructions are open to change as life circumstances fluctuate with complex interactions, will contribute to improving living conditions and support survival strategies for foreign migrants in our communities. This will also inform the development of new models of cross-cultural mission programmes and encounters, which promote dialogue and hospitality with, and not for, migrants. In the sections that follow, I briefly highlight a few important issues, which emerged from the lived realities of migrants in Johannesburg, before presenting an analysis of statements from Abdul who inspired this contribution.

Since 2008, foreigners in South Africa have been under intermittent xenophobic threats and sporadic attacks as were repeated in 2015. ${ }^{3}$ Foreign migrants continue to experience threats and hostility has worsened recently, given that poor communities are reeling under the impact of lockdown and poverty increased in the face of unemployment conditions acerbated by COVID-19. Although the South African government announced an ambitious plan to address this situation, the R50 billion package has been marred with corruption allegations as the political elites took an opportunity to enrich themselves through flouting tender regulations - leaving the poor short-changed in the face of the devastating impact of COVID-19. Consequently, this has impacted negatively on the government's:

[Q]uest to protect South African citizens from the novel coronavirus ... which brought about a shutdown of the economy, which in turn resulted in a shock in the labour market and a big change in the way people went about doing their work. (Stats SA 2020:7)

There is a need for the government to provide more social and economic safety nets for all people who live within the borders of the country as enshrined in the constitution, which recognises that 'South Africa belongs to all who live in it ...' (The Freedom Charter 1955). As the South African President Ramaphosa announced on the 21st of April 2020:

Poverty and food insecurity have deepened dramatically in the course of just a few weeks. To reach the most vulnerable families in the country, we have decided on a temporary 6-month Coronavirus grant. We will direct R50 billion towards relieving the plight of those who are most desperately affected by the coronavirus. This means that child support grant beneficiaries will receive an extra R300 in May and from June to October they will receive an additional R500 each month. All other grant beneficiaries will receive an extra R250 per month for the next six months. In addition, a special Covid-19 Social Relief of Distress grant of R350 a month for the next 6 months will be paid to individuals who are currently unemployed and do not receive any other form of social grant or UIF payment. (Ramaphosa 2020:6)

Despite the statistics, which show that 'the official unemployment rate increased by 1.7 percentage points to 32.5\% in Q4: 2020 compared to Q3: 2020' (Stats SA 2020:13), it is important to mention that foreign migrants were initially left out of this intervention by the governments. This was despite the recognition that COVID-19 restrictions impacted on the majority of migrants whose income heavily relies on

3.For more details, you can read: 'Xenophobic violence in democratic South Africa' available from: https://www.sahistory.org.za/article/xenophobic-violencedemocratic-south-africa. Accessed 21 March 2021. 
the informal sector. By implication, they were part of the 'most vulnerable families in the country' who were exposed to poverty and insecurity as a result of the pandemic. Other than marginalisation, migrants continue to face hostile sentiments from local South Africans, and this was reflected in a recent Facebook (FB) comments, which I observed during the weekend of 24 January 2021 after the media (ENCA 2021b) reported the looting and burning of foreignowned shops in Durban, KwaZulu Natal. In response to a report on these disturbances, some of the Facebook comments read as follows (ENCA 2021a):

They must go home ... bafunani vele [anyway, what do they want?] (n.p.)

Another socialite tried to explain the phenomenon in a more critical and engaging way (ENCA 2021a):

Nothings new, its [sic] January so there is hunger then people will loot ... its [sic] criminal acts of poverty and foreigners are victims'. (n.p.)

The response from the second FB socialite attempted to link this looting with crime. In a sense, this is a possibility as some of these have become common scenes when there are protests similar to the one, which was organised by former uMkhonto Wesizwe War Veterans (MK) who previously threatened to drive foreigners out of Durban but later denied any involvement in the latest attacks (Nxumalo, 26 January 2020).

This was despite them leading a protest march, which shut down foreign-owned shops in November 2020 (ENCA 2020). For a second day after violent clashes between MK Vets and officials, similar scenes had played out on Monday after scores of MK Vets and members of the People's Revolutionary Movement took to the streets to protest over the presence of undocumented foreign nationals operating businesses in the CBD:

\footnotetext{
"'Before they came to this country, we were not this hungry; our people were working, our people had income and there was not a huge number of drugs. They have destroyed our country and our youth are deep into drugs because of them", one of the protesters told the reporters.' (Nxumalo S and Nxumalo M, 03 November 2020)
}

It would seem like very little has changed because these hostile accusations directed to foreign migrants are reminiscent with what I observed back in 2015 (Mpofu 2015:159) where some migrants retorted:

'[B]ecause I'm not a South African ... the question will always be; if your country was nice why did you come here in South Africa ... I'm one of the people who was affected with that xenophobic thing ... we lost everything you know ... simply because you are a foreigner.' (Focus group participant, 30 August 2015)

These statements emerged from a discussion with foreign migrants in 2015 when they recounted traumatic experiences in the face of violence and relayed how their livelihoods had been impacted by xenophobic threats and violence as locals demanded that they leave South Africa:

'They were there you know, telling us you people we don't want you here ... they said if things were right in your country, then what are you doing here ... go back we don't want you here ...' (Focus group participant, 26 April 2015)

Although not exhaustive or representative of all migrants, these quotes are used as examples to highlight the contextual challenges of hostility directed to foreign migrants in South Africa. The current discussion is interested in these experiences with the intersection and cultural orientation in identity formation processes.

How do individual migrants navigate the hostile religious and cultural contexts to develop new identity as a survival strategy for survival? In the section that follows, this question is addressed through an analysis of the statements, which shed some light on the experiences of one Abdul who took part in focus group discussions.

As I will outline below, this brief reflection demonstrates how contested processes of socio-economic and religious transformation reflect the significance of the role played by religion on how identity constructions are open to change (and sometimes present a dilemma), as life circumstances fluctuate with complex interactions as survival strategies.

\section{I'm Somali and I'm Christian - An emerging identity in the context of migration}

$[B]$ ad enough I'm Somalian and I'm Christian and all those times I was hiding myself because those Somalians were the ones who received me and taking care of me. (Abdul, Focus group participant, Mayfair, 30 August 2015) (in Mpofu 2015:154)

This statement was relayed by Abdul as he profoundly reflected on the dilemma regarding how he had to navigate a diverse cultural and religious landscape in Mayfair, Johannesburg. At the time of taking part in a focus group discussion on the 30th of August 2015, Abdul had moved to Mayfair so that he could get support from fellow Somalis who provided accommodation for him after he moved from Soweto at the peak of xenophobic violence. He explained how his informal business was burned down and destroyed, driving him out of the violent community and seeking shelter in Mayfair. At the time that Abdul moved from Soweto, he had converted to Christianity and was attending worship services in one congregation without feeling intimidated or threatened by his Muslim background. However, things changed when he moved to stay with Somalis, most of them are devoted Muslims. He now had to manage his Christian commitment without creating tensions with Muslims who otherwise could not take care of him if they discovered that he had converted to Christianity. Therefore, Abdul had to be creative in navigating the cross-cultural and religious landscape. 
At a time when dealing with hostility from local South Africans, Abdul simultaneously had to manage his relationship within the Muslim community who supported him, and this had to be performed in ways that will help him avoid possible rejection from his Somali Muslim brothers and sisters. In an article 'Religious conversions in forced migration: Comparative cases of Afghans in India and Iranians in Turkey', Akcapar (2019:1) examined the link between religious conversions of two groups of refugees who converted from Islam to become members of the 'born-again' evangelical Christian groups operating in South Asia and West Asia and observed that 'a combination of contextual and institutional factors explain this religious change and help us understand the sociocultural and political impacts of conversion'. A study conducted by the Research Directorate, Immigration and Refugee Board of Canada, Ottawa (2014:3) also noted that in Muslim communities, 'those suspected of conversion faced harassment' from fellow community members. This could explain why Adbul had to carefully handle his Christian identity after moving into a predominantly Muslim community in Mayfair.

Sadouni (2019) has conducted an intensive study on Muslims in Mayfair, Johannesburg, where he analysed Somalis' modes of place making and articulated how Somali migrants 'reinvent a Somali urban identity in Johannesburg [in ways] that give them power to mark and territorialise their economic, political and religious modes of beings Somali in Mayfair' (2019:1). He describes this process as 'racialisation from below'. For Abdul, the reinvention of Somali urban identity in complex identities, given that he not only has to 'mark and territorialise' the economic and political, but he must also devote more time to carefully navigate the religious terrain, has a double dimension - drawing from both the Muslim and Christian communities. The Somalis in Mayfair maintain a close bond with each other whilst collectively manoeuvring new cultural landscapes. This practice resonates with what Arel (2014) described in the models of immigrant acculturation and suggests that there is no complete rejection of the heritage culture for migrants, unless they are stressed. However, any suspected conversion is treated as a threat and converts may be subjected to rejection.

Therefore, Abdul's conversion to Christianity meant that he had to navigate both communities in ways that ensured his survival, which depended on his connection and networks with Somali Muslims. Being embedded in both cultural and religious practices, which draw from Somali heritage culture and the Christian community of the protestant church in Mayfair, required a carefully managed life. Such navigation is consistent with what Vertovec (2009) has identified as 'simultaneous embeddedness'. There are two kinds of 'embeddedness', the first being 'relational embeddedness', one deriving from 'personal relations with one another, including norms, sanctions, expectations and reciprocity' and the second being 'structural embeddedness' - one which identifies different levels of social relationships where other players get involved beyond direct economic transactions.
Given his religious experiences, Abdul had to leverage the two kinds of embeddedness by resorting to bicultural negotiation, which simultaneously integrates him into the host culture, whilst he secretly maintained religious ties with the Christian community. This was clearly reflected in the statement below:

' $[A] 11$ those times I was hiding myself because those Somalians were the ones who received me and taking care of me ... I decided to come to church but even coming to church I had to hide. Even going out I must hide, I have to make sure that no one can see me ...' (Abdul, 30 August 2015)

Hiding his Christian identity revealed the extent of the dilemma that Abdul had to endure as a Somali migrant living among Somali Muslims and worshipping in a Christian protestant congregation. After losing his business during the xenophobic violence, Abdul was left homeless and felt vulnerable, and he was forced to seek shelter among Somali Muslims. To ensure reception of hospitality among Somalis, his Christian identity had to be hidden as he 'embedded' himself within the Muslim religious community so that he was welcomed and accepted into the community. This meant that he had to live with tensions between his religious, cultural and national identity as he navigated Muslim, Christian and Somali terrains. Abdul's experiences shed light on the identity challenges that migrants endure as they struggle to survive in a culturally diverse context characterised by hostility and fear of rejection.

Pointing out 'bad enough I'm Somalian and Christian' implies that Abdul was aware of the consequences of living among Muslim Somalis when he had converted to Christianity. Being a Somalian (a country predominantly Muslim) and finding himself living with other Somalis after converting to Christianity challenged his spirituality in the face of deprivation. It has been observed that migrants often rely on their spirituality as means to cope with the challenges they face in African communities (Shaw et al. 2019:1). People like Abdul often draw on religion as 'social capital' as part of survival strategies and these experiences present an opportunity for a theology of migration which emerges out of the lived realities of migrants. Teresa Okure (1993:22) identified these conditions as 'violent up-rootedness/ displacement, economic poverty, anxiety about the future, and the loss of national identity, political freedom and personal dignity'. Unfortunately, the Church as an institution has not been able to adequately provide support and protection to Muslim converts so that they are not forced to stay in Muslim communities to maintain material support.

Abdul's experience highlights the complex identity formation processes, which generate hybrid religious and cultural identities. These modes of identity landscapes do not isolate or privilege certain aspects of African identity but creatively merge diverse religious and cultural expressions to forge new identities and new meanings in rapidly changing sociocultural, racial political and economic landscapes. Therefore, in developing new identity conceptual frameworks for an African identity and citizenship, we need to consider not 
only the racial, cultural and national categories but also the intersecting religious trajectories, which generate new forms of hybrid African identities. We must also remember that some traditional, cultural and religious symbols and practices were imported from the West during the colonial era and may no longer denote relevant meanings, which they had during the colonial and apartheid dispensations. It is important to always remember that although there were territorial nomadic spaces, the introduction of formal borders in Africa was a part of the western project of colonisation, and in South Africa, the apartheid system not only segregated Africans from non-whites, but native Africans were also grouped into tribal townships and homelands. The reference made to colonial history is intended to challenge the odious notion that African migrants are foreigners, whereas other western and Asian migrants are labelled in cosy terms such as expatriates, tourists and all. Commendable progress has been made since 1994 by the African National Congress (ANC) government, which continues to address these challenges, but divisions and these misconceptions remain deeply entrenched in South African society and present complex challenges for African migrants who often become easy targets during xenophobic attacks.

\section{Conclusion}

Sketching the experiences of Abdul demonstrated how contested processes of socio-economic and religious transformation reflect the significance of the role played by religion on identity constructions, which are fluid and fluctuate with complex interactions in search of survival strategies. This contribution highlights how these encounters generate hybrid identities and discourses with new boundaries which, although fluid, are often volatile and reminiscent with historical legacies of colonialism and apartheid. Loss of identity as a result of displacement in South African migrant communities is particularly compounded by the historical racial divisions that have roots from the apartheid era. Therefore, decolonising borders should pay attention to emerging hybrid identity discourses, which move beyond ethnic, national and racial boundaries.

These intersecting identity formation processes also reflect how framing an inclusive African identity still remains a challenge as a result of pitfalls, which arise from the colonial and racial challenges. This contribution demonstrates a need to broaden the scope of African identity processes to include the role of religion and religiosity alongside intersecting discourses on culture, race and sexuality through contextually grounded interpretive approaches to African identity. This will ensure that the role of religion is taken seriously in migration and identity processes, whilst we do not lose consciousness to the historical legacies of colonialism and apartheid.

\section{Acknowledgements}

The author wishes to acknowledge the Faculty of Theology and Religion at the University of Pretoria for identifying the theme of Fullness of Life which inspired this article.

\section{Competing interests}

The author declares that he has no financial or personal relationships that may have inappropriately influenced him in writing this article.

\section{Author's contributions}

B.M. is the sole author of this research article.

\section{Ethical considerations}

This article followed all ethical standards for research without direct contact with human or animal subjects.

\section{Funding information}

This research received no specific grant from any funding agency in the public, commercial or not-for-profit sectors.

\section{Data availability}

Data sharing is not applicable to this article as no new data were created or analysed in this article. However, it is important to mention that data discussed here was collected for a $\mathrm{PhD}$ research project which has been acknowledged herein.

\section{Disclaimer}

The views and opinions expressed in this article are those of the author and do not necessarily reflect the official policy or position of any affiliated agency of the author.

\section{References}

Adam, J., Römhild, R., Bojadžijev, M., Knecht, M., Lewicki, P., Polat, N. et al. (eds.), 2019 Europa dezentrieren: Globale Verflechtungen neu denken, Campus, Frankfurt.

Adogame, A., 2013, The African Christian diaspora: New currents and emerging trends in world Christianity, Bloomsbury, London.

Adogame, A., Osemime, U. \& Spickard, J.V. (eds.), 2010, Religion crossing boundaries: Transnational religious and social dynamics in Africa and the New African Diaspora, Brill, Leiden.

Adogame, A. \& Shankar, S. (eds.), 2012, Religion on the move! New dynamics of religious expansion in a globalizing World, Brill, Leiden.

Agamben, G., 2005, The state of exception, Chicago University Press, Chicago, IL.

Agbiji, O.M. \& Swart, I., 2015, 'Religion and social transformation in Africa: A critical and appreciative perspective', Scriptura 114, 1-20. https://doi.org/10.7833/114$0-1115$

Akcapar S.K., 2019, 'Religious conversions in forced migration: Comparative cases of Afghans in India and Iranians in Turkey', Journal of Eurasian Studies 10(1), 61-74. https://doi.org/10.1177/1879366518814666

Arel, S.K., 2014, 'Ethnic identity in children of immigrants: Identity pathways, academic outcomes, and the mediating effect of parents and peers', A PhD dissertation (Education and Psychology), University of Michigan.

Bekker, S.B., Dodds, M. \& Khosa, M.M. (eds.), 2001, Shifting African identities, Human Sciences Research Council, Pretoria.

Bekker, S.B. \& Leildé, A., 1999, Identity construction 'From Above': The Western Cape province as case study. An Interim Report on research into emerging provincial identities in the Western Cape, Stellenbosch University, Department of Sociology, Stellenbosch.

Benatar, D., 2008, 'Justice, diversity and racial preference: A critique of affirmative action', South African Law Journal 125(2), 274-306.

Boraine, A.L., 2006, 'Transitional justice: A holistic interpretation', Journal of International Affairs 60(1), 17-27.

Castles, S., 2001, 'Studying social transformation', International Political Science Review/Revue Internationale De Science Politique 22(1), 13-32. https://doi. org/10.1177/0192512101221002

De Gruchy, J. \& Villa-Vicencio, C. (eds.), 1994, Doing theology in Contex, South African perspectives, Orbis Books, New York, NY. 
E News Channel Africa (ENCA), 2020, MKMVA members shut down foreign-owned shops in the Durban CBD yesterday and want South Africans to be put first. Is the government taking a strong enough stance against potential xenophobia? government taking a strong enough stance against potential xenophobia? watch/?v=649994445711249.

E News Channel Africa (ENCA), 2021a, Face Book Post with comments from the Public. Foreign owned shops in Durban torched, looted, viewed 26 January 2021 from https://www.enca.com/news/foreign-owned-shops-durban-cbd-torchedlooted.

E News Channel Africa (ENCA), 2021b, 'Foreign-owned shops in Durban CBD torched, looted', Tuesday 26 January 2021, viewed 21 March 2021, from https://www. enca.com/news/foreign-owned-shops-durban-cbd-torched-looted.

Erasmus, Z., 2010, 'Reformulating racialised citizenship(s) for South Africa's interregnum', Transformations 74, 47-65. https://doi.org/10.1353/trn.2010.0006

Habib, A., 2013, South Africa's suspended revolution, University of Ohio Press, Athens, GA.

Immigration and Refugee Board of Canada, 2014, Somalia: Treatment of non-Muslims, including those who commit apostasy, by society and extremist groups, including al-Shabaab, viewed 24 March 2021, from https://www.justice.gov/sites/default/ files/pages/attachments/2015/12/08/som104854.e.pdf.

Mpofu, B., 2015, 'When the people move, the Church moves: A critical exploration of the interface between Migration and Theology through a Missiological study of selected congregations within the Uniting Presbyterian Church of Southern Africa in Johannesburg', PhD thesis, University of KwaZulu-Natal S.A.

Mpofu, B. \& Settler, F., 2017, 'The limits of social responsibility with respect to religion and migration in South Africa', Journal for the Study of Religion 30(2), 12-31. https://doi.org/10.17159/2413-3027/2017/v30n2a1

Ndlovu-Gatsheni, S.J., 2018, 'Decolonising borders, decriminalising migration and rethinking citizenship', in H. Magidimisha, N. Khalema, L. Chipungu, T. rethinking citizenship', in $\mathrm{H}$. Magidimisha, N. Khalema, L. Chipungu,
Chirimambowa \& T. Chimedza (eds.), Crisis, identity and migration in post-colonial Chirimambowa \& T. Chimedza (eds.), Crisis, identity and migration in post-colonial
Southern Africa. Advances in African economic, social and political development, pp. 23-37, Springer, New York.

Nel, R., 2009, 'Finding a place under the African sun' the search for new identities in post-colonial (Southern) Africa evidenced in students' writing in the Missiology course, Christian Action for Anti-racism and Reconciliation at UNISA', Missionalia; Southern African Journal of Mission Studies 37(3), 138-152.
Ngwena, C., 2018, What is Africanness? Contesting nativism in race, culture and sexualities, University Law Press (PULP), Pretoria.

Ngwena, C., 2019, Celebrating Africa Month: Building inclusive Africanness, viewed 21 March 2021, from https://www.up.ac.za/news/post 2814001-celebrating-africamonth-building-inclusive-africanness?utm_source=hootsuite\&utm medium $=\&$ utm_term $=\& u t m \_$content $=\& u t m \_$campaign $=$.

Nxumalo, S., 2021, MK vets deny involvement in torching of foreign-owned shops in Durban city centre, 26 January 26, IOL Report, viewed 27 January 2021, from https:// www.iol.co.za/mercury/news/mk-vets-deny-involvement-in-torching-of-foreignowned-shops-in-durban-city-centre--74b3e629-1c1c-4b45-ac1e-a6fd08831ed0.

Nxumalo, S. \& Nxumalo, M., 2020, 'MK Vets shut down foreign-owned shops in Durban city centre', IOL News, 03 November 2020, viewed 27 January 2021, from https://www.iol.co.za/news/south-africa/kwazulu-natal/watch-mk-vets-shutdown-foreign-owned-shops-in-durban-city-centre-41228c63-68d0-4fc1-b26ef3f1230f3c29.

Okure, T., 1993, Africa: A refugee camp experience, SCM Press, New York.

Orobator, A., 2005, From crisis to Kairos: The mission of the Church in the time of HIV/ AIDS, refugees and poverty, Pauline, Nairobi.

Pillay, J., 2020, 'COVID-19 shows the need to make church more flexible', Transformation 37(4), 266-275. https:doi.org/10.1177/0265378820963156

Ramaphosa, C., 2020, 'Additional coronavirus COVID-19 economic and social relief measures', viewed 21 April 2021, from https://www.gov.za/speeches/president-cyrilramaphosa\%20additional-coronavirus-covid-19\%20economic-and-social-relief\#.

Sadouni, S., 2019, Racialisation from below: Race and place-making in the New South Africa. In: Muslims in Southern Africa. Migration, diasporas and citizenship, Palgrave Macmillan, London. https://doi.org/10.1057/978-1-137-46708-9_4

Shaw, S.A., Peacock, L., Ali, L.M., Pillai, V. \& Husain, A., 2019, Religious coping and challenges among displaced Muslim female refugees', Affilia 34(4), 518-534. https://doi.org/10.1177/0886109919866158

Stats SA, Department of Statistics South Africa, 2020, viewed 21 March 2021, from http://www.statssa.gov.za/publications/P0211/P02114thQuarter2019.pdf.

The Freedom Charter, 1955, viewed 21 March 2021, from https://disa.ukzn.ac.za/sites/ default/files/DC\%20Metadata\%20Files/Gandhi-Luthuli\%20Documentation\%20 Centre/TheFreedomCharter1955/TheFreedomCharter1955.pd.

Vertovec, S., 2009, Transnationalism, Routledge, London. 